\title{
The effect of metastatic focus on survival after cytoreductive nephrectomy in renal cell carcinoma: Experience of a single center
}

\section{Renal hücreli karsinomda metastaz odağının sitoredüktif nefrektomi sonrası sağkalıma etkisi: Tek merkez deneyimi}

\author{
İsmail Selvi ${ }^{1}$, Erdem Öztürk $^{2}$ \\ ${ }^{1}$ Karabük Üniversitesi Eğitim ve Araştırma Hastanesi, Üroloji Kliniği, Karabük \\ ${ }^{2}$ Sağlık Bilimleri Üniversitesi Dr. Abdurrahman Yurtaslan Ankara Onkoloji Eğitim ve Araştırma Hastanesi, \\ Üroloji Kliniği, Ankara
}

Dergiye Ulaşma Tarihi: 01.07.2019 Dergiye Kabul Tarih 09.08.2019 Doi: 10.5505/aot.2019.48403

\section{ÖZET}

GİRIŞ ve AMAÇ: Metastatik renal hücreli karsinomda (RHK) yeni geliştirilen hedefe yönelik tedavilere rağmen halen sağkalım oranları düşüktür. En sık metastaz gözlenen alanlar arasında yer alan akciğer, karaciğer ve kemik tutulumu içerisinde, özellikle de kemik metastazı saptanan olgular daha kötü prognoz ile ilişkilendirilmektedir. Çalışmamızda RHK'da metastaz odağının onkolojik sonuçlara etkisini belirlemeyi ve genel sağkalıma etki eden diğer prognostik faktörleri de değerlendirmeyi amaçladık.

YÖNTEM ve GEREÇLER: Ocak 2009-Aralık 2016 tarihleri arasında, tanı anında metastaz saptanan ve sitoredüktif nefrektomi yapılan RHK olgularından, verilerine tam olarak ulaşlabilen 35 hasta retrospektif olarak değerlendirildi. Hastaların demografik, patolojik, klinik verileri, nefrektomi sonrası progresyon durumları ve sağkalım verileri kaydedilerek, hastalar kemik metastazı bulunanlar (Grup I) ve sadece visseral organ metastazı olanlar (Grup II) şeklinde iki gruba ayrıldı.

BULGULAR: Hastaların ortalama yaşı $59.20 \pm 11.72$ olup, ortanca 11 (2-90) aylık takip süresi boyunca 25 (\% 71.4) hastada progresyon, 27 (\%77.1) hastada ölüm gerçekleşmiştir. Grup I' de IMDC ( $\mathrm{p}=0.008)$ ve MSKCC risk skorları $(\mathrm{p}=0.025)$ Grup II' ye göre daha yüksek bulunurken, yine Grup I' de progresyon (\%85.0 vs. \%53.3, $\mathrm{p}=0.04)$ ve ölüm (\%90.0 vs. $\% 60.0, \mathrm{p}=0.036)$ oranları anlamlı olarak daha yüksek gözlendi. Öngörülen genel sağkalım süresi, Grup I'de anlamlı olarak daha düşük bulundu (18.60 vs. 43.60 ay, p=0.036). Çok değişkenli analizde, IMDC skoru progresyonsuz sağ kalımı öngörmede; Fuhrman derecesi, metastaz odağının kemik olması ve IMDC skoru ise genel sağkalımı öngörmede bağımsız prediktif faktörler olarak bulundu.

TARTIŞMA ve SONUÇ: Kemik metastazlı RHK olgularında özellikle de eşlik eden visseral organ metastazı, multipl kemik tutulumu, aksiyel kemik tutulumlarında genel sağkalımın azaldığı görülmektedir. Bu hastalarda, beyin dışındaki diğer visseral organ tutulumu olan olgulara göre daha kötü prognoz gözlendiğinden, daha yakın takip gerekmektedir. Ayrıca hayat kalitesini düşüren kemikle ilişkili olay gözlenme oranları da daha yüksek olduğundan, uygulanabilecek kemiğe yönelik farklı lokal palyatif tedaviler konusunda daha dikkatli davranılmalıdır.

Anahtar Kelimeler: Kemik metastazı, onkolojik sonuçlar, progresyon, renal hücreli karsinom, sitoredüktif nefrektomi, visseral metastaz

\section{ABSTRACT}

INTRODUCTION: Despite the newly developed targeted therapies in metastatic renal cell carcinoma (RCC), survival rates are still low.The most common metastatic areas are lung, liver and bone. Among these, especially cases with bone metastasis are associated with worse prognosis. In this study, we aimed to determine the effect of metastatic focus on oncologic outcomes in RCC and to evaluate other prognostic factors affecting overall survival.

METHODS: Between January 2009 and December 2016, 35 patients with metastatic RCC who underwent cytoreductive nephrectomy were evaluated retrospectively.Demographic, pathological, clinical data, progression status and survival outcomes after nephrectomy were recorded and the patients were divided into two groups: those with bone metastases (Group I) and those with only visceral organ metastasis (Group II). 
RESULTS: The mean age of the patients was $59.20 \pm 11.72$ years.During the median follow-up period of 11 (290) months, 25 patients (71.4\%) had progression and 27 patients (77.1\%) died.IMDC risk score $(\mathrm{p}=0.008)$,MSKCC risk score $(\mathrm{p}=0.025)$, progression rate $(85.0 \%$ vs $53.3 \%, \mathrm{p}=0.04)$ and mortality rate $(90.0 \%$ vs $60.0 \%), \mathrm{p}=0.036$ ) were found to be significantly higher in Group I. The predicted overall survival was significantly lower in Group I (18.60 vs. 43.60 months, $\mathrm{p}=0.036$ ).In multivariate analysis, IMDC score was found to be independent predictor for progression-free survival. On the other hand, Fuhrman grade, bone involvement and IMDC score were independent predictors for overall survival.

DISCUSSION AND CONCLUSION: It is seen that overall survival decreases especially in the presence of accompanying visceral organ metastasis, multiple or axial bone involvement in RCC with bone metastases.Closer follow-up is required for cases with bone metastasis because these patients have worse prognosis than those with visceral organ involvement except for brain.In addition, the rates of bone-related events are higher in these patients and cause decrease in quality of life.Therefore, different local palliative treatments for bone should be chosen more carefully.

Keywords: Bone metastasis, cytoreductive nephrectomy, oncologic outcomes, progression, renal cell carcinoma, visceral metastasis

\section{GİRiş}

Renal hücreli karsinom (RHK) tüm yetişkin malignitelerinin yaklaşı $\% 3$, ünü oluşturmakta olup hastaların \% 20-25'i tanı anında metastatik evrededir. Lokalize veya lokal ileri evre hastalarda, radikal nefrektomi sonrası takipte metastaz gelişme oranı ise yaklaşık \% 30-35' tir (1). En çok metastaz saptanan alanlar akciğer, karaciğer, kemik olmakla birlikte, adrenal bez, pankreas, beyin, tiroid ve cilt olmak üzere pek çok organda metastaz gözlenebilmektedir (2). Ortalama sağkalım süresi 10-12 ay, iki yıllık sağkalım oranı \%18-20 olan metastatik hastalıkta özellikle kemik ve beyin metastazlarında daha kötü prognoz gözlenmektedir (3).

Kemik metastazlarına olguların \% 3040 gibi oldukça yüksek bir kısmında rastlanılmaktadır (3). Uluslararası Böbrek Kanseri Çalışma Grubu hedefe yönelik tedaviye rağmen, kemik metastazlarında diğer metastatik bölgelere göre anlamlı düzeyde daha kötü genel sağkalım gözlendiğini bildirmiştir (Hazard ratio:1.4). Çeşitli yayınlara göre, beş yıllık ortalama sağkalım oranı yaklaşık \%15' tir $(1,4)$. Osteolitik özellik gösteren bu metastazlar, genellikle patolojik fraktür, spinal kord kompresyonu, hiperkalsemi gibi kemik ilişkili olaylara (KİO) neden olabilmektedir (4). Çoğu tedavi seçeneklerine dirençli olduklarından, palyatif tedavi amaciyla basit rezeksiyondan amputasyona çeşitli cerrahi girişimlere ihtiyaç olabilmektedir.

Çalışmamızda ciddi morbidite ve daha kısa sağkalım ile ilişkili olduğu bildirilen kemik metastazlı RHK olguları ile beyin dışı visseral organ metastazı gösteren RHK olgularını kıyaslayarak, metastaz odağının onkolojik sonuçlara etkisini ve genel sağkalıma etki eden diğer prognostik risk faktörlerini belirlemeyi amaçladık.

\section{GEREÇ ve YÖNTEM}

Kliniğimizde Ocak 2009-Aralık 2016 tarihleri arasında, tanı anında klinik evrelemede metastaz saptanan ve sitoredüktif amaçlı radikal nefrektomi yapılan RHK olgularından, verilerine tam olarak ulaşlabilen 35 hasta retrospektif olarak değerlendirilerek çalışmaya dahil edildi. Hastaların demografik verileri, vücut kitle indeksi (VKİ), histolojik tümör tipi, tümörün Fuhrman derecesi, nekroz varlığ1, tümör tarafi, lokalizasyonu, patolojik tümör boyutu, metastaz saptanan organ, nefrektomi sonras1 takip süresi, progresyon ve genel sağkalım oranları kaydedildi. Tüm hastalarda sitoredüktif nefrektomi sonrası birinci basamak hedefe yönelik tedavi uygulanmıştır.

$$
\text { Metastatik RHK olgularında }
$$

konvansiyonel immunoterapi ve birinci basamak hedefe yönelik tedavi planlaması için geliştirilmiş ve valide edilmiş bazı prognostik risk modelleri bulunmaktadır. Bunlar içerisinde en yaygın olarak kullanılanlar, International Metastatic RCC Database Consortium (IMDC) modeli ve Memorial Sloan-Kettering Cancer Center (MSKCC) risk modelidir. IMDC risk skorunu tahmin etmek için kullanılan prognostik faktörler; Karnofsky performans skoru, tanidan tedaviye kadar geçen süre, hemoglobin ve kalsiyum seviyeleri, trombosit ve nötrofil sayılarıdır. MSKCC risk skorunu hesaplamak için ise, trombosit ve nötrofil sayıs1 yerine laktat dehidrojenaz düzeyi kullanılmaktadır. Her iki 
model de hastalara ait kötü prognostik faktörlerin sayısına göre, hastaları iyi, orta ve kötü prognoz olarak üç risk grubuna ayırmaktadır (5). Çalışmamıza dahil ettiğimiz hastalara ait IMDC ve MSKCC prognostik risk skorları da hesapland.

Kemik metastazı bulunan 20 hasta Grup I, sadece visseral organ metastazı bulunan 15 hasta Grup II olarak siniflandirilarak, hastalar randomizasyon yapılmadan iki gruba ayrıldı. Her iki grup onkolojik sonuçlar açısından karşılaştırıldı.

\section{İstatistiksel Analiz}

Kolmogorov-Smirnov ve Shapiro-Wilk testleri ile normalite durumu değerlendirildikten sonra, iki grup arasındaki farklılıkları karşılaştırırken, normal dağ 1 lım gösteren sürekli değişkenler için Independent sample $t$ test, normal dağılım göstermeyen sürekli değişkenler için MannWhitney U testi, kategorik değişkenler için Pearson ki-kare analizi kullanıldı. Sağkalım analizi için Kaplan-Meier, buna etkili olan değişkenleri belirlemede Cox regresyon analizi kullanıldı. Analizler IBM SPSS Statistics 21 (IBM, Armonk, NY USA) yazılımı kullanılarak yapıldı. $\quad \mathrm{p}<0.05$ değerleri istatistiksel olarak anlamlı kabul edildi.

\section{BULGULAR}

Çalışmada yer alan 35 hastanın ortalama yaşı $59.20 \pm 11.72$ olup, hastaların $28(\% 80) ' \mathrm{i}$ erkek, 7 (\%20)'si kadındı. Nefrektomi sonras1 ortanca 11 (2-90) aylik takipte 25 (\% 71.4) hastada progresyon, 27 (\%77.1) hastada ölüm gerçekleşmiştir. Grup I'de yer alan 7 hastada sadece kemikte, 9 hastada kemik ve akciğerde, 3 hastada kemik ve karaciğerde, 1 hastada ise kemik, akciğer ve karaciğerde metastaz gözlendi. Grup II'de ise, 8 hastada sadece akciğerde, 3 hastada sadece karaciğerde, 4 hastada ise hem akciğer hem de karaciğerde metastaz saptanmıştır. Hastaların demografik, patolojik, klinik verileri ve onkolojik sonuçları Tablo 1, 2 ve 3' te görülmektedir.

Kemik metastazlı grupta IMDC $(\mathrm{p}=0.008)$ ve MSKCC risk skorları $(\mathrm{p}=0.025)$ visseral organ metastazı olan gruba göre daha yüksek bulunurken, yine bu grupta progresyon $(\% 85.0$ vs. $\% 53.3, \mathrm{p}=0.04)$ ve ölüm ( $\% 90.0$ vs. $\% 60.0, \mathrm{p}=0.036$ ) oranları anlamlı olarak daha yüksek gözlendi (Tablo 1). Kemik metastazlı 20 hastaya ait alt grup analizinde ise, eşlik eden visseral organ metastazı, multipl kemik tutulumu, uzun kemikler dışındaki aksiyel kemik tutulumlarında genel sağkalımın azaldığı, Kİ saptanan hastalarda progresyon oranlarının arttığı görüldü (Tablo 2, 3).

Grup I'de öngörülen progresyonsuz sağkalım süresi (10.27 vs. 17.70 ay, $\mathrm{p}=0.091$ ) daha düşük olmakla beraber, istatistiksel olarak anlamlı değildi (Şekil 1). Öngörülen genel sağkalım süresi ise, Grup I'de anlamlı olarak daha düşük bulundu (18.60 vs. 43.60 ay, $\mathrm{p}=0.036$ ) (Şekil 2).

Tek değişkenli analizde, IMDC ve MSKCC risk skorları progresyonsuz sağ kalımı öngören bağımsız prediktif faktörler olduğu bulunurken; genel sağkalımı öngören faktörlerin VKI, Fuhrman derecesi, metastaz odağının kemik olması, IMDC ve MSKCC risk skorları olduğu gözlendi. Çok değişkenli analizde ise, IMDC skoru progresyonsuz sağ kalımı öngörmede; Fuhrman derecesi, metastaz odağının kemik olması ve IMDC skoru ise genel sağkalımı öngörmede daha anlamlı prediktif faktörler olarak değerlendirildi (Tablo 4).

\section{TARTIŞMA}

RHK olgularında akciğerden sonra en çok metastaz gözlenen yer kemiktir ve metastatik RHK hastalarının yaklaşık üçte birinde kemik tutulumu bulunmaktadır (6). Ancak tümörün niçin sıklıkla kemiğe metastaz yaptığ yeterince anlaşılamamıştır. Kemik metastazı gelişimi, tümör hücreleri ve kemik mikroçevresi arasında bir dizi etkileşim gerektiren multifaktöriyel bir süreçtir (7). Tümörün indüklediği osteoklast aktivitesine bağlı olarak salınımı artan Transforming growth faktör- $\beta$, kemik morfogenetik proteinleri ve kemik sialoproteinleri gibi faktörlerin salınımı sonucu oluştuğunu belirten çalışmalar bulunmaktadır $(8,9)$. In vivo RHK metastaz modellerinde, tümör hücrelerinin kemiğe yerleşmesi ve proliferasyonunda cadherin-11' in önemli bir rol oynadığ 1 da belirtilmiştir (10).

Günümüzde yeni saptanan moleküler yolaklar sayesinde, hedefe yönelik tedaviler sağkalım oranlarını uzatmaktadır. $\mathrm{Bu}$ durum ise, tanı anında kemik tutulumu olmasa bile takip sürecinde kemikte yeni metastatik 
odakların oluşma olasılığının artmasıyla sonuçlanabilmektedir (11). Kemik metastazı, metastatik RHK olgularında kötü sağkalımla ilişkili bağımsız bir prognostik risk faktörü olarak tanımlanmaktadır. Bu hastalarda ortanca genel sağkalım süresi çeşitli yayınlarda 17 ay ile 23.2 ay arasında bildirilmiştir $(11,12)$. Kalra ve ark. (13) tirozin kinaz inhibitörlerinin (TKI) kullanıma girdiği dönemde, kemik metastazlı RHK olgularında ortanca genel sağkalımı 22 ay olarak, TKİ kullanımı öncesi dönemde ise bu süreyi 14 ay olarak saptamıştır. Biz de bu oranlara benzer şekilde kemik tutulumu olan hastalarda genel sağkalım süresini 18.6 ay olarak saptadik.

Literatürde bildirilen pek çok çalışmaya göre, clear cell dışı histopatolojik alt tip ve MSKCC risk skorlaması, genel sağkalım açısından daha kötü prognostik faktörler olarak tanımlanmıştır $(6,11,12)$. Santoni ve ark. (12) ek olarak, ECOG performans skoru ve eşlik eden akciğer veya lenf nodu metastazı varlığını, kemik metastazlı hastalarda genel sağkalımın bağımsız belirleyicileri olarak belirledi. Ruatta ve ark. (11) ise, buna ilaveten birden fazla kemik tutulumu, eşlik eden visseral organ metastazı ve uzun kemiklere k1yasla spinal vertebra ve sakrumdaki tutulum varlığında genel sağkalımın daha kötü olduğunu göstermiştir. Özellikle soliter ve vücuttaki uzun kemiklerde saptanan metastazların cerrahi rezeksiyonu daha kolay olabileceğinden, bu hastalarda gözlenen daha uzun sağkalım süreleri bu duruma atfedilmiştir. Multimodal hedefe yönelik tedaviler yanı sıra, özellikle soliter kemik metastazı olan olgularda metastazektominin ve gereksinim halinde uygulanacak palyatif kemik cerrahisinin veya diğer lokal kemik tedavilerinin sağkalımı uzattığını, KİO'ya bağlı morbidite ve mortaliteleri ise azalttığını bildiren başka yayınlar da mevcuttur $(11,14,15)$. Nitekim Jung ve ark. (16) sitoredüktif nefrektomiyi takiben, tek odakta kemik metastazı olan, iyi prognostik özelliklere sahip olgularda, cerrahi rezeksiyon sonrası beş yıllık sağkalımın \%54'e kadar ulaşabildiğini belirtmiştir.

Kemik metastazlı olguları içeren geniş hasta serili yeterli prospektif çalışmalar olmadığından, cerrahi rezeksiyon, radyoterapi, kriyoterapi, radyofrekans ve vertebroplasti gibi kemik tutulumuna yönelik farklı lokal tedavi seçeneklerinden hangilerinin önerilebileceğine dair standart bir yaklaşım bulunmamaktadır. Ruatta ve ark. (11) farklı tedavi seçeneklerinin genel sağkalım üzerinde anlamlı bir farklılık oluşturmadığını bildirse de, hastalarında çoğunlukla cerrahi rezeksiyon uygulandığ 1 için, bu durumun bir bias faktörü olarak sonuçlarını etkileyebileceğini ifade etmiştir. Çalışmamızdaki multivariate analiz sonuçlarına göre, genel sağkalımı belirleme açısından tümörün Fuhrman derecesi, IMDC risk skoru ve visseral organ tutulumuna kiyasla kemik tutulum varlığ 1 daha kötü prognoza sahiptir. Yine literatürle uyumlu olarak, multipl kemik tutulumu, eşlik eden visseral organ metastazı ve aksiyel sistemdeki kemiklerde tutulum olmasının genel sağkalımı kısalttığını saptadık. Kemik rezeksiyonu uygulanması ise bulgularımıza göre genel sağkalımı anlamlı olarak etkilememektedir. Her ne kadar univariate analize göre, Karnofsky skoru, IMDC ve MSKCC risk skorları genel sağkalımı öngörmede anlamlı bulunsa da, multivariate analize göre, IMDC skorunun daha anlamlı bir prediktif faktör olduğunu saptadık.

Kemik tutulumu olan metastatik RHK hastalarında yaşanan önemli bir sorun da dayanılmaz ağrı ve patolojik fraktürlerin eşlik ettiği KIO' ya bağlı hayat kalitesinde gözlenen olumsuz etkilenmedir. KİO gözlenme oranı literatürde $\%$ 56-74 arasında bildirilmiştir $(11,17)$. Biz ise bu oranı çalışmamızda $\% 60$ olarak gözledik. KİO saptanan bu hastalarda, genel sağkalım anlamlı olarak etkilenmezken, hastalık progresyonunun anlamlı olarak arttığını gözlemledik. Toyoda ve ark. (18) tanı anında kemik metastazı varlı̆̆ında, sonradan kemik tutulumu gelişen olgulara göre genel sağkalımın (25 ay vs. 63 ay) daha kötü olduğunu göstermiştir. Biz ise, çalışmamızdaki kemik metastazı saptanan grupta, olguların hepsinde tanı anında kemik tutulumu mevcut olduğundan, böyle bir değerlendirme yapamadik.

Çalışmamızın retrospektif dizaynı, düşük hasta sayısı içermesi, bu nedenle randomizasyon oluşturulamaması, kısa takip süreleri ve izlem sonuçlarının tek merkeze ait olması başlıca kısıtlayıcı faktörlerdir. Ayrıca sitoredüktif nefrektomi sonrası uygulanmış olan hedefe yönelik tedavilerin onkolojik sonuçlara etkisinin incelenmemiş olması da çalışmamızın başka bir kısıtlılığıdır. 
Sonuç olarak, visseral organ metastazının eşlik ettiği, multipl veya aksiyel kemik tutulumu olan kemik metastazlı RHK olgularında, beyin harici diğer visseral organ tutulumu saptanan olgulara kıyasla genel sağkalım belirgin olarak azalmaktadır. Bu hastalarda, yüksek oranlarda KİO gözlenebileceği için daha yakın takip gerekmektedir ve çeşitli lokal palyatif tedaviler konusunda hastalar bilgilendirilmelidir.

Çıkar çatışması: Yok.

Tablo 1: Hastaların demografik, patolojik, klinik verileri ve onkolojik sonuçları

\begin{tabular}{|c|c|c|c|c|}
\hline Parametreler & Grup I (n:20) & Grup II (n:15) & Toplam (n:35) & p değeri \\
\hline Yaş & $58.00 \pm 12.55$ & $60.80 \pm 10.73$ & $59.20 \pm 11.72$ & $\dagger 0.493$ \\
\hline VKİ & $26.63 \pm 3.14$ & $25.65 \pm 3.29$ & $26.21 \pm 3.19$ & $\dagger 0.379$ \\
\hline $\begin{array}{c}\text { Cinsiyet }(\mathrm{n}, \%) \\
\text { erkek } \\
\text { kadın }\end{array}$ & $\begin{array}{c}16(80.0) \\
4(20.0)\end{array}$ & $\begin{array}{c}12(80.0) \\
3(20.0)\end{array}$ & $\begin{array}{c}28(80.0) \\
7(20.0)\end{array}$ & $\$ 0.668$ \\
\hline $\begin{array}{l}\text { Tümör tarafi }(\mathrm{n}, \%) \\
\text { sağ } \\
\text { sol }\end{array}$ & $\begin{array}{c}7(35.0) \\
13(65.0)\end{array}$ & $\begin{array}{l}6(40.0) \\
9(60.0)\end{array}$ & $\begin{array}{l}13(37.1) \\
22(62.9)\end{array}$ & $\$ 0.762$ \\
\hline $\begin{array}{c}\text { Tümör lokalizasyonu (n,\%) } \\
\text { üst pol } \\
\text { orta pol } \\
\text { alt pol } \\
\text { hiler }\end{array}$ & $\begin{array}{l}8(40.0) \\
0(0.0) \\
8(40.0) \\
4(20.0)\end{array}$ & $\begin{array}{l}4(26.7) \\
2(13.3) \\
4(26.7) \\
5(33.3)\end{array}$ & $\begin{array}{c}12(34.3) \\
2(5.7) \\
12(34.3) \\
9(25.7)\end{array}$ & $\$ 0.382$ \\
\hline Patolojik tümör boyutu $(\mathrm{cm})$ & $7.76 \pm 2.96$ & $7.35 \pm 3.05$ & $7.58 \pm 2.96$ & $\dagger 0.695$ \\
\hline $\begin{array}{l}\text { Histolojik alt tip }(\mathrm{n}, \%) \\
\text { clear cell } \\
\text { papiller tip 1 } \\
\text { papiller tip 2 } \\
\text { kromofob }\end{array}$ & $\begin{array}{c}15(75.0) \\
2(10.0) \\
3(15.0) \\
0(0.0)\end{array}$ & $\begin{array}{c}12(80.0) \\
2(13.3) \\
0(0.0) \\
1(6.7)\end{array}$ & $\begin{array}{c}27(77.1) \\
4(11.4) \\
3(8.6) \\
1(2.9)\end{array}$ & $\$ 0.296$ \\
\hline $\begin{array}{c}\text { Fuhrman grade }(\mathrm{n}, \%) \\
2 \\
3 \\
4\end{array}$ & $\begin{array}{l}6(30.0) \\
7(35.0) \\
7(35.0)\end{array}$ & $\begin{array}{l}3(20.0) \\
6(40.0) \\
6(40.0)\end{array}$ & $\begin{array}{c}9(25.8) \\
13(37.1) \\
13(37.1)\end{array}$ & $\$ 0.799$ \\
\hline $\begin{array}{c}\text { Nekroz varlığ } 1(\mathrm{n}, \%) \\
\text { Var } \\
\text { Yok }\end{array}$ & $\begin{array}{l}11(55.0) \\
9(45.0)\end{array}$ & $\begin{array}{l}12(80.0) \\
3(20.0)\end{array}$ & $\begin{array}{l}23(65.7) \\
12(34.3)\end{array}$ & $\$ 0.123$ \\
\hline $\begin{array}{l}\text { Takip süresi (ay) } \\
\text { median (minimum- } \\
\text { maksimum) }\end{array}$ & $9.5(2.0-86.0)$ & $28.0(2.0-90.0)$ & $11.0(2.0-90.0)$ & $\S 0.113$ \\
\hline $\begin{array}{c}\text { Karnofsky skoru } \\
>80 \\
<80\end{array}$ & $\begin{array}{c}7(35.0) \\
13(65.0)\end{array}$ & $\begin{array}{l}9(60.0) \\
6(40.0)\end{array}$ & $\begin{array}{l}16(45.7) \\
19(54.3)\end{array}$ & $\$ 0.142$ \\
\hline
\end{tabular}




\begin{tabular}{|c|c|c|c|c|}
\hline IMDC skoru & $4.25 \pm 1.33$ & $2.93 \pm 1.38$ & $3.69 \pm 1.49$ & $\dagger 0.008 *$ \\
\hline $\begin{array}{c}\text { IMDC risk grubu } \\
\text {-İyi } \\
\text {-Orta } \\
\text {-Kötü }\end{array}$ & $\begin{array}{c}0(0.0) \\
2(10.0) \\
18(90.0)\end{array}$ & $\begin{array}{c}0(0.0) \\
7(46.7) \\
8(53.3)\end{array}$ & $\begin{array}{c}0(0.0) \\
9(25.7) \\
26(74.3)\end{array}$ & $+0.014 *$ \\
\hline MSKCC skoru & $4.05 \pm 1.14$ & $3.00 \pm 1.51$ & $3.60 \pm 1.39$ & $\dagger 0.025^{*}$ \\
\hline $\begin{array}{c}\text { MSKCC risk grubu } \\
\text {-İyi } \\
\text {-Orta } \\
\text {-Kötü }\end{array}$ & $\begin{array}{c}0(0.0) \\
2(10.0) \\
18(90.0)\end{array}$ & $\begin{array}{c}0(0.0) \\
7(46.7) \\
8(53.3)\end{array}$ & $\begin{array}{c}0(0.0) \\
9(25.7) \\
26(74.3)\end{array}$ & $\ddagger 0.014 *$ \\
\hline Progresyon oran1 $(\mathrm{n}, \%)$ & $17(85.0)$ & $8(53.3)$ & $25(71.4)$ & $\mp 0.04 *$ \\
\hline Genel mortalite oranı $(\%)$ & $18(90.0)$ & $9(60.0)$ & $27(77.1)$ & $\$ 0.036^{*}$ \\
\hline
\end{tabular}

VKİ: Vücut kitle indeksi; IMDC: International Metastatic RCC Database Consortium;

MSKCC: Memorial Sloan-Kettering Cancer Center

$\dagger$ Independent sample T test, $\S$ Mann-Whitney $U$ test $\$$ Ki-kare testi

$* \mathrm{p}<0.05$ (Gruplar arasında istatistiksel anlamlı bir fark vardır.)

Tablo 2: Kemik metastazı olan hastaların klinik verileri

\begin{tabular}{|l|l|}
\hline Parametreler & $\mathbf{n}(\%)$ \\
\hline Eşlik eden visseral organ metastazı & \\
-Var & $\mathbf{1 3}(\mathbf{6 5 . 0})$ \\
-Yok & $\mathbf{7 ( 3 5 . 0 )}$ \\
\hline Tutulan kemik sayısı & \\
-Soliter & $\mathbf{6}(\mathbf{3 0 . 0})$ \\
-Multipl & $\mathbf{1 4}(\mathbf{7 0 . 0})$ \\
\hline Tutulan kemik lokalizasyonu & \\
-Uzun kemikler & $\mathbf{7 ( 3 5 . 0 )}$ \\
-Spinal vertebra & $\mathbf{9 ( 4 5 . 0 )}$ \\
-Sakrum & $\mathbf{4 ( 2 0 . 0 )}$ \\
\hline Kemik rezeksiyonu durumu & \\
-Var & $\mathbf{7 ( 3 5 . 0 )}$ \\
-Yok & $\mathbf{1 3}(\mathbf{6 5 . 0})$ \\
\hline Kemikle ilişkili olay varlı̆̆ı & \\
-Var & $\mathbf{1 2}(\mathbf{6 0 . 0})$ \\
-Yok & $\mathbf{8}(\mathbf{4 0 . 0})$ \\
\hline
\end{tabular}


Tablo 3: Kemik metastazı olan hastaların onkolojik sonuçları

\begin{tabular}{|c|c|c|c|c|}
\hline & $\begin{array}{c}\text { Progresyon oranı } \\
(\mathrm{n}, \%)\end{array}$ & $\mathbf{p}$ & $\begin{array}{c}\text { Genel mortalite oranı } \\
(\mathbf{n}, \%)\end{array}$ & p \\
\hline $\begin{array}{l}\text { Eşlik eden visseral organ } \\
\text { metastazı } \\
\text {-Var } \\
\text {-Yok }\end{array}$ & $\begin{array}{l}13(100) \\
4(57.1)\end{array}$ & $+0.010 *$ & $\begin{array}{l}13(100) \\
5(71.4)\end{array}$ & $\$ 0.042 *$ \\
\hline $\begin{array}{l}\text { Tutulan kemik sayısı } \\
\text {-Soliter } \\
\text {-Multipl }\end{array}$ & $\begin{array}{l}4(66.7) \\
13(92.9)\end{array}$ & +0.133 & $\begin{array}{l}4(66.7) \\
14(100.0)\end{array}$ & $\$ 0.023 *$ \\
\hline $\begin{array}{l}\text { Uzun kemik tutulumu } \\
\text {-Var } \\
\text {-Yok }\end{array}$ & $\begin{array}{l}4(57.1) \\
13(100.0)\end{array}$ & $+0.010 *$ & $\begin{array}{l}5(71.4) \\
13(100)\end{array}$ & $\$ 0.042 *$ \\
\hline $\begin{array}{l}\text { Kemik rezeksiyonu durumu } \\
\text {-Var } \\
\text {-Yok }\end{array}$ & $\begin{array}{l}7(100.0) \\
10(76.9)\end{array}$ & $\$ 0.168$ & $\begin{array}{l}6(85.7) \\
12(92.3)\end{array}$ & $\$ 0.639$ \\
\hline $\begin{array}{l}\text { Kemikle ilişkili olay varlığı } \\
\text {-Var } \\
\text {-Yok }\end{array}$ & $\begin{array}{l}12(100.0) \\
5(62.5)\end{array}$ & $+0.021 *$ & $\begin{array}{l}11(91.7) \\
7(87.5)\end{array}$ & $\$ 0.761$ \\
\hline
\end{tabular}

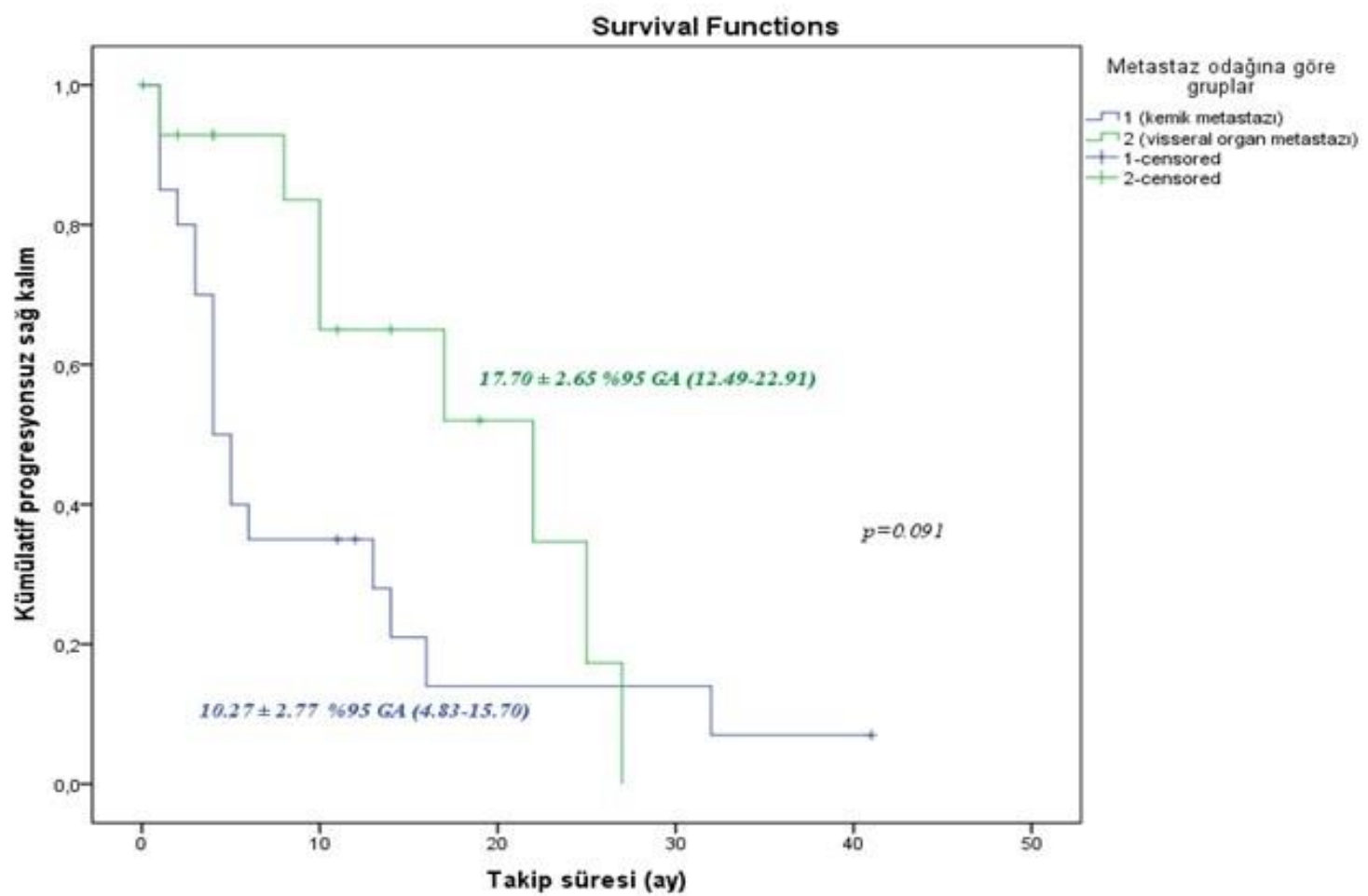

Şekil 1: Metastaz odağına göre hastaların progresyonsuz sağkalımına ait Kaplan-Meier eğrileri

Adress for correspondence: Uzm. Dr. İsmail Selvi, Şirinevler Mahallesi, Alpaslan Cad. No: 1, Merkez / KARABÜK 78200 Karabük - Türkiye e-mail: ismselvi33@hotmail.com

Available at www.actaoncologicaturcica.com

Copyright $\odot$ Ankara Onkoloji Hastanesi 


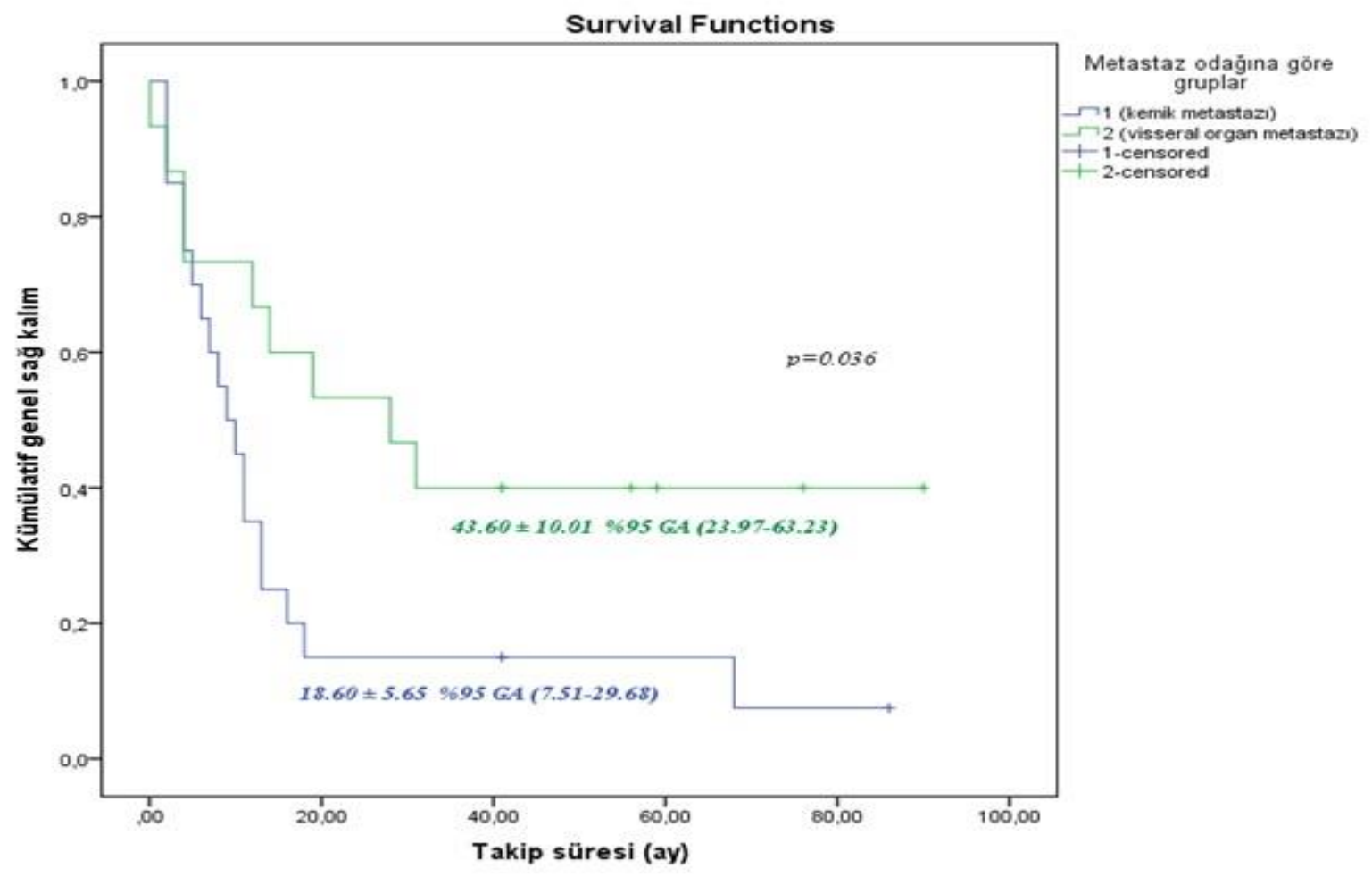

Şekil 2: Metastaz odağına göre hastaların genel sağkalımına ait Kaplan-Meier eğrileri

Tablo 4: Progresyonsuz sağkalım ve genel sağkalım için prediktif faktörler

\begin{tabular}{|c|c|c|c|c|c|c|c|c|}
\hline \multirow[b]{3}{*}{ Progresyonsuz sağ kalım } & \multicolumn{4}{|c|}{ Univariate Model } & \multicolumn{4}{|c|}{ Multivariate Model } \\
\hline & \multirow{2}{*}{ HR } & \multicolumn{2}{|c|}{$\% 95 \mathrm{GA}$} & \multirow{2}{*}{$\mathrm{p}$} & \multirow{2}{*}{ HR } & \multicolumn{2}{|c|}{$\% 95 \mathrm{GA}$} & \multirow{2}{*}{$\mathrm{p}$} \\
\hline & & Alt & Üst & & & Alt & Üst & \\
\hline Yaş & 1.020 & 0.982 & 1.060 & 0.299 & & & & \\
\hline Cinsiyet & 1.107 & 0.364 & 3.366 & 0.858 & & & & \\
\hline VKİ & 1.062 & 0.937 & 1.202 & 0.346 & & & & \\
\hline Histopatolojik alt tip & 1.026 & 0.665 & 1.581 & 0.909 & & & & \\
\hline Fuhrman grade (I-IV) & 1.066 & 0.630 & 1.803 & 0.812 & & & & \\
\hline Patolojik tümör boyutu & 1.079 & 0.960 & 1.213 & 0.201 & & & & \\
\hline Nekroz varllğ 1 & 1.035 & 0.454 & 2.358 & 0.935 & & & & \\
\hline Metastaz odağ & & & & & & & & \\
\hline (kemik vs. visseral organ) & 2.030 & 0.859 & 4.807 & 0.106 & & & & \\
\hline Karnofsky skoru & 1.119 & 0.507 & 2.475 & 0.779 & & & & \\
\hline IMDC skoru & 1.389 & 1.018 & 1.894 & $0.038^{*}$ & 1.389 & 1.018 & 1.894 & $0.038^{*}$ \\
\hline MSKCC skoru & 1.217 & 0.910 & 1.627 & $0.045^{*}$ & & & & \\
\hline
\end{tabular}




\begin{tabular}{|c|c|c|c|c|c|c|c|c|}
\hline \multirow[b]{3}{*}{ Genel sağ kalım } & \multicolumn{4}{|c|}{ Univariate Model } & \multicolumn{4}{|c|}{ Multivariate Model } \\
\hline & \multirow{2}{*}{ HR } & \multicolumn{2}{|c|}{$\% 95 \mathrm{GA}$} & \multirow{2}{*}{$\mathrm{p}$} & \multirow{2}{*}{ HR } & \multicolumn{2}{|c|}{$\% 95 \mathrm{GA}$} & \multirow{2}{*}{$\mathrm{p}$} \\
\hline & & Alt & Üst & & & Alt & Üst & \\
\hline Yaş & 1.020 & 0.985 & 1.057 & 0.257 & & & & \\
\hline Cinsiyet & 1.433 & 0.568 & 3.617 & 0.446 & & & & \\
\hline VKİ & 1.168 & 1.039 & 1.314 & $0.010 *$ & & & & \\
\hline Histopatolojik alt tip & 1.096 & 0.697 & 1.723 & 0.691 & & & & \\
\hline Fuhrman grade (I-IV) & 1.916 & 1.130 & 3.251 & $0.016 *$ & 1.751 & 1.031 & 2.974 & $0.038 *$ \\
\hline Patolojik tümör boyutu & 1.099 & 0.978 & 1.235 & 0.114 & & & & \\
\hline Nekroz varlığ 1 & 1.563 & 0.682 & 3.584 & 0.291 & & & & \\
\hline \multicolumn{9}{|l|}{ Metastaz odağı } \\
\hline (kemik vs. visseral organ) & 2.309 & 1.018 & 5.235 & $0.045^{*}$ & 2.538 & 1.026 & 6.289 & $0.044^{*}$ \\
\hline Karnofsky skoru & 2.439 & 1.104 & 5.376 & $0.027 *$ & & & & \\
\hline IMDC skoru & 1.757 & 1.287 & 2.399 & $<0.001 *$ & 1.757 & 1.287 & 2.399 & $<0.001 *$ \\
\hline MSKCC skoru & 1.510 & 1.148 & 1.987 & $0.003 *$ & & & & \\
\hline
\end{tabular}

VKİ: Vücut kitle indeksi; IMDC: International Metastatic RCC Database Consortium;

MSKCC: Memorial Sloan-Kettering Cancer Center

Cox regresyon analizi $\quad * \mathrm{p}<0.05$ (Gruplar arasında istatistiksel anlamlı bir fark vardır.)

\section{REFERANSLAR}

1. Siegel RL,Miller KD, Jemal A. Cancer Statistics, CA Cancer J Clin. 2018;68(1):7-30.

2. Hoffman NE, Gillet MD, Cheville JC. Difference in organ system of distant metastses by mRCC subtypes. J Urol 2008;180:474-7.

3. Woodward E, Jagdev S, McParland L, et al. Skeletal complications and survival in renal cancer patients with bone metastases. Bone 2011;48(1):160e6.

4. Heng DY, Xie W, Bjarnason GA, et al. Progression-free survival as a predictor of overall survival in metastatic renal cell carcinoma treated with contemporary targeted therapy. Cancer 2011;117(12): 2637e42.

5. Kim JK, Kim SH, Song MK, et al. Application of the International Metastatic Renal Cell Carcinoma Database Consortium and Memorial Sloan Kettering Cancer Center Risk Models in Patients with Metastatic Non-Clear Cell Renal Cell Carcinoma: A Multi-Institutional Retrospective Study Using the Korean Metastatic Renal Cell Carcinoma Registry.Cancer Res Treat 2019; 51 (2):758-768.

6. Kalra S, Verma J2, Atkinson BJ, et al. Outcomes of Patients With Metastatic Renal Cell Carcinoma and Bone Metastases in the Targeted Therapy Era. Clin Genitourin Cancer. 2017;15(3):363-370.

7. Santoni M, Santini D, Massari F, et al. Heterogeneous drug target expression as possible Adress for correspondence: Uzm. Dr. İsmail Selvi, Şirinevler Mahallesi, Alpaslan Cad. No: 1, Merkez / KARABÜK 78200 Karabük - Türkiye e-mail: ismselvi33@hotmail.com

Available at www.actaoncologicaturcica.com

Copyright $\odot$ Ankara Onkoloji Hastanesi basis for different clinical and radiological response to the treatment of primary and metastatic renal cell carcinoma: suggestions from bench to bedside. Cancer Metastasis Rev. 2014;33:321-31.

8. Mundy GR. Metastasis to bone: causes, consequences and therapeutic opportunities. Nat Rev Cancer. 2002;2:584-93.

9. Chirgwin JM, Guise TA. Molecular mechanisms of tumor-bone interactions in osteolytic metastases. Crit Rev Eukaryot Gene Expr. 2000;10:159-78.

10. Satcher RL, Pan T, Cheng CJ, et al. Cadherin-11 in renal cell carcinoma bone metastasis. PLoS One. 2014;9:e89880.

11. Ruatta F, Derosa L, Escudier B, et al. Prognosis of renal cell carcinoma with bone metastases: Experience from a large cancer centre.Eur J Cancer. 2019;107:79-85.

12. Santoni M, Conti A, Procopio G, et al. Bone metastases in patients with metastatic renal cell carcinoma: are they always associated with poor prognosis? J Exp Clin Cancer Res 2015;34:10.

13. Guida A, Escudier B, Albiges L. Treating patients with renal cell carcinoma and bone metastases.Expert Rev Anticancer Ther. 2018;18(11):1135-1143.

14. Fottner A, Szalantzy M, Wirthmann L, et al. Bone metastases from renal cell carcinoma: patient survival after surgical treatment. BMC Muscoskel Disord 2010;11:145.

15. Jung ST, Ghert MA, Harrelson JM, et al. Treatment of osseous metastases in patients with renal cell 
carcinoma. Clin Orthop Relat Res 2003;409:223e31.

16. Evenski A1, Ramasunder S, Fox W, et al. Treatment and survival of osseous renal cell carcinoma metastases.J Surg Oncol. 2012;106(7):850-5.

17. Santini D, Procopio G, Porta C, et al. Natural history of malignant bone disease in renal cancer: final results of an Italian bone metastasis survey. PLoS One 2013;8(12), e83026.

18. Toyoda Y, Shinohara N, Harbayashi $T$, et al. Survival and prognostic classification of patients with metastatic renal cancer to bones. Eur Urol 2007; 52:163-9. 